\title{
Critical Success Factor for Labuhan Bajo Airport Public-Private Partnership Investment Pilot Project
}

\author{
Irma Yusfidal \\ ${ }^{1}$ Junior Expert Planner, Planning Bureau - General Secretary, Ministry of Transportation-Indonesia \\ ${ }^{1}$ Doctoral Program of Transportation, School of Architecture, Planning and Policy Development, Institut Teknologi Bandung, Jl. Ganesha No.10, \\ Bandung 40132, Indonesia

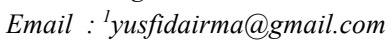

Keywords

PPP; financing; pilot project; airport

\begin{abstract}
The government often faces budget constraints and financial gaps between necessity and real allocation funds. It makes them must be more selective when prioritizing infrastructure development. Moreover, providing adequate transport infrastructure and sustainability is crucial for the government. Government must innovate by creating a conducive investment climate to encourage the participation of private and state-owned enterprises in infrastructure financing. Innovation financing through Private Funding and PPP schemes is directed to infrastructure with high economic and financial feasibility. PPP schemes in the air transportation sector particularly in Indonesia have not been successfully implemented until 2018. Therefore, the government has initiated several PPP projects as pilot projects to encourage PPP implementation in the Transportation Sector. One of them is Labuan Bajo International Airport. Labuan Bajo Airport is in West Manggarai Regency as a gateway to enter the Komodo Island area. Labuan Bajo airport is one key infrastructure that supports The Big 5 Super Priority Destinations of Indonesia by the Indonesia Ministry of Tourism and Creative Economy. This paper aims to examine critical success factors and interfere factors of the PPP pilot project for Labuan Bajo Airport. This paper uses an exploratory descriptive method to examine every factor that supports the success of the PPP implementation process in the air transportation sector based on qualitative data. The study will also explore the planning process through analysis of PPP Book documents from 2010-2020 (content analysis) to historically examine the process of proposing PPP project activities and examine the factors that support the success or delay the PPP pilot project within the Ministry of Transportation based on stakeholder approach. The planning and preparation stage plays a critical role in efforts to prepare comprehensive, reliable, and feasible projects. The feasible project can minimize project uncertainty and gain attract private sector investment
\end{abstract}

\section{INTRODUCTION}

The inevitable infrastructure development challenge is government budget constraints. Initially, development funding was handled by conventional funding (government budget/APBN) but currently facing budget constraints made the paradigm shift through opening up opportunities for private involvement in developing and developed countries (Ng et al., 2012). Based on the National Medium-Term Development Plan (RPJMN), this shift is believed to accelerate the provision of infrastructure and increase economic growth in the medium and long term. The presence of the private sector is not only solving budget constraints but also providing optimal quality of infrastructure services (Gardaindonews, 2018) that adopt their experience and technology innovation (Fleta-Asín \& Muñoz, 2020). The PPP scheme gives the public and private sector a mutual advantage through financial funding and the technical aspect (Aladag \& Isik, 2018). Based on the 20202024 National Medium-Term Development Plan (RPJMN), there are three (3) funding schemes : 1) Private Funding and PPP schemes for projects that have high economic and financial feasibility (high value of IRR), 2) National Corporate funding for project that has high economic feasibility but still financially marginal, and 
3) Government funding for basic service infrastructure that high economic feasibility, but not financially feasible.

Air transport infrastructure is crucial for Indonesia as the largest archipelago country with 17.508 islands scattered between the Indian and Pacific Oceans. The airport has a key role to connect the isolated area to the main region and transferring people and goods. Initially in Indonesia, most airports are not economically feasible even would be funded by National Budget. Budget constraints make the government must set priorities due to the allocation of new development airports (21 new airports), airport maintenance (238 airports). This condition makes the government only accommodates the demand-growth of traffic passengers in minimum service standards. The characteristics of airport development need high cost and a low value rate of Return (IRR) (Carnis \& Yuliawati, 2013). Therefore, development needs several alternative financing schemes to face budget limitations including the PPP scheme, National Sharia Loan, foreign loan, and the utilization partnership scheme. The main airport that is presumably economically profitable, would be offered to the state's enterprise through utilization cooperation and the government only handled feeder airports to facilitate transport services in remote areas.

Based on Indonesia Presidential Regulation Number 38 of 2015, PPP is a collaboration between the government and Business Entities in the Provision of Infrastructure for the public interest by referring to the required specifications, which partially or wholly use the resources of the Business Entity with the risk-sharing between the parties. The Business Entities include State-Owned Enterprises, Regional-Owned Enterprises, private business entities, foreign legal entities, or cooperatives. PPP schemes in the airport sector until 2018 have not been successfully implemented, Government initiated a pilot project in Labuan Bajo Airport as a role model of the successful implementation. Labuan Bajo Airport is an airport supporting the Labuan Bajo tourist area in the West Manggarai Regency which was designated as one of "The Big 5 Super Priority Destinations of Indonesia" by the President of the Republic of Indonesia (Mediaindonesia, 2020). Labuan Bajo tourism destination is conducted to develop prime tourism destination that targets the middle and upper-class target market. In addition, Komodo Island as a worldwide unique tourism destination expectantly can promote the magnitude of tourism attractiveness. Based on the results of the DGCA study, the potential passenger demand for Labuhan Bajo Airport is huge. Potential demand for domestic and foreign tourists will reach 3,726,000 passengers in 2044 and the projected demand for international routes includes Singapore, Kuala Lumpur, Manila, and Bangkok. Bid Award was held in December 2019 and after the qualification process, the winner was determined. The auction winner who will operate Labuhan Bajo Airport is PT. Cinta Airport Flores (PT. CAF), a consortium of PT. Cardig Aero Services and Changi Airports Mena Pte Ltd (Idris, 2020).

The planning process includes choosing the project, selecting an appropriate scheme based on transport characteristics, preparing the PPP Document is the critical process. Most PPP Project proposals are rejected and unsuccessful attract investors. Therefore, Government set a pilot project PPP with full government support that is different from the previous PPP scheme process. Our research is structured to identify support factors and obstruct factors related to the successful implementation of the PPP pilot project. This research aim is to examine the support factors and interference factors of Labuan Bajo Airport as a PPP pilot project. This research uses a qualitative approach through the exploratory descriptive method. The methods will examine each factor that supports the success of the PPP implementation. The examination process will be based on 10 years PPP Book document to understand differences in the preparation planning stages related to previous unsuccessful projects. There are quite several studies that discuss the key success factors for PPP, but only this research that specifically discusses the pilot project at the airport is available in Indonesia as a developing country. The structure of this paper started with a literature review about the important support factors of the PPP implementation in section 2. Moreover, the next section will explain the brief method of collecting data, analysis method, and exploration in section 3. Discussion and analysis will be presented in section 4 . In the end, the conclusion will be presented in section 5 . 


\section{LITERATURE REVIEW}

The PPP is not a transfer of government duty in providing public services. The PPP is a private investment in infrastructure projects in financing, design, development, appropriate maintenance, or operation through a government cooperation agreement (Bappenas, 2016). PPP projects on the source of funding or return investment can be based on fees for service usage (user charge) or payment by the Government based on the availability of services (availability payments) (Wibowo 2017). Airport concession scheme will be vary based on the airport sized such as Large Airport (international airport) by privatization, Medium Airport with selfsupporting funding (National Govenrnment and Private Sector), while Small Airport using mixed scheme (basic and parking handled by local government, building by private sector and ATC facilities by national government. (Sugimura \& Kato, 2021).

Based on Minister of Finance Regulation: 260/PMK.08/2016, Availability Payment is periodic payments by the Minister/Head of Institutions to the Business Entity for the availability of infrastructure services in accordance with the quality and/or criteria as specified in the PPP Agreement. The requirements of AP projects are no revenue from the service users, a project that is not financially feasible, or infrastructure is free of charge. There is a different characteristic for the airport as a node and highway as a network for PPP projects. PPP Project with AP schemes was implemented in the highway sector (Ryan and Menezes, 2014) and also by the user charge scheme (Ng, Wong and Wong 2012). PPP Scheme for airports usually user charge, not an availability payment. Most airport projects will gain optimal concession contracts by combining nonaeronautical revenue and aeronautical revenues (Engel et al., 2018). Non-aeronautical revenues such as shops, restaurants, hotels, and parking lot support airport primary services, whereas aeronautical revenues are revenues from passenger fees and airline fees (Engel et al., 2018). Therefore, user charges will be more optimum and beneficial rather than availability payment for economic potential airports. It will be different for the airport located in a remote area and non-economically feasible. Availability Payment is needed to maintain services and facilitate people from isolated areas. Knowing the best revenue scheme is crucial to gaining optimal revenue from PPP Projects. Before continuing to the discussion session, the determination of the variables should be explained as a brief literature review to complete this research as follows.

Table 1. PPP Implementation Succes Factor

\begin{tabular}{|c|c|c|c|c|}
\hline No & Country & PPP Object & Variables & Source \\
\hline 1 & Malaysia & Infrastructure & $\begin{array}{l}\text { 1) Good Governance, 2) positive legal frameworks 3) } \\
\text { conducive economic policy 4) committed public and } \\
\text { private sector 5) available market }\end{array}$ & (Ismail 2013) \\
\hline 2 & Vietnam & Infrastructure & $\begin{array}{l}\text { Public sector factor, private sector factor, procurement } \\
\text { process, project information, external factor and risk } \\
\text { management }\end{array}$ & $\begin{array}{l}\text { (Tuan Hai et al., } \\
\text { 2022) }\end{array}$ \\
\hline 3 & Indonesia & Infrastructure & $\begin{array}{l}\text { 1) Comprehensive government ability 2) PPP institutional } \\
\text { quality, 3) incentives for investors 4) law certainty and } 5 \text { ) } \\
\text { opportunistic behaviour }\end{array}$ & (Maramis 2018) \\
\hline 4. & Perancis & Infrastructure & $\begin{array}{l}\text { Government ability including (1) to identify high-value } \\
\text { projects to be financed by PPP (2) ability to select service } \\
\text { models (3) ability to agree on rewards (4) ability to work } \\
\text { with detailed contracts } \\
\text { strengthening contracts }\end{array}$ & $\begin{array}{l}\text { (Estache and } \\
\text { Saussier 2014) }\end{array}$ \\
\hline 5. & Singapore & Infrastructure & $\begin{array}{l}\text { Interrefere factors are 1) minimum government support, } \\
\text { 2) funding availability, 3) construction lag time, 4) poor } \\
\text { experience in PPP, (5) insecure government, }\end{array}$ & $\begin{array}{l}\text { (Hwang, Zhao } \\
\text { and Gay 2013) }\end{array}$ \\
\hline 6. & New Zealand & Highway & $\begin{array}{l}\text { Transfer of demand risk, inefficiency in tendering process, } \\
\text { firms capital structure }\end{array}$ & $\begin{array}{c}\text { (Ryan and } \\
\text { Menezes 2014) }\end{array}$ \\
\hline 7. & Hongkong & Infrastructure & $\begin{array}{l}\text { Relationship management such as commitment and } \\
\text { participation of high officer, defining objectives and } \\
\text { target, integration inter organization }\end{array}$ & $\begin{array}{l}\text { (Zou, et al. } \\
\text { 2014) }\end{array}$ \\
\hline 8. & Korea & Expressway & $\begin{array}{l}\text { Acceptable level of user charge, cost effectiveness and } \\
\text { financial attractiveness } \\
\text { government and private strong commitment, risk sharing, } \\
\text { and political and institutional climate support PPP }\end{array}$ & $\begin{array}{l}\text { (Ng, Wong and } \\
\text { Wong 2012) } \\
\text { (Bae and Joo } \\
\text { 2016) }\end{array}$ \\
\hline
\end{tabular}




\begin{tabular}{ccclcc}
\hline No & Country & PPP Object & & Source \\
9. & Australia and & Infrastructure & (1) Robustness of business case expansion; (2) Quality of & (Liu, Wang and \\
& China & & project brief; (3) Public sector competence; (4) & Wilkinson 2016) \\
& & governance structures; (5) effective communication; (6) & balance between consolidation and competition; and (7) \\
& & transparency level when tendering processes.
\end{tabular}

Source: Literature Review, 2021

As shown in table 1, it can be summarized that key success factors to PPP implementation are

1) Project bankability or financial aspect (Johnson, McCormally, \& Moore, 2002; Forrer, Kee, \& Zhang, 2002, Ryan and Menezess, 2014),

2) Economic \& Technical Aspect (van Ham \& Koppenjan, 2001) present from fair and transparent tendering (Ryan and Menezess, 2014), the private sector's ability to comply with the requirement (Tuan Hai et al., 2022; Liu, Wang, and Wilkinson 2016)

3) Law and Politics Aspect such as positive legal frameworks that support a climate of investment. It could be policies to simplify the investment process and incentives to attract investors (Ismail 2013, Tuan Hai et al., 2022; Maramis 2018; Estache and Saussier 2014; Hwang, Zhao and Gay 2013)

4) Social Issue including community around airport and passengers related to an acceptable level of user charges (Ng, Wong and Wong 2012)

5) Public-sector competence (government) particularly capability person in charge as PJPK and team. The executing agency must be advance PPP experience to promoted high commitment, identify high-value projects to be financed by PPP, ability to select service models etc (Estache and Saussier 2014; Zou, et al. 2014; Hwang, Zhao and Gay 2013; Liu, Wang and Wilkinson 2016).

\section{METHODS}

The research method uses a descriptive method that can be interpreted as a procedure that investigated by describing the current state of the subject/object based on the visible facts (Nawawi, 2003). The descriptive method used Document Analysis with the Content Analysis method. This method is used to reveal the situation of document writing through gathering information and comparing documents. The examination process will be based on 10 years PPP Book document to understand the differences in the preparation planning stages related to previous unsuccessful projects. The documents studied are the planning documents for the PPP Book include the 2010-2014 PPP Book, 2015 PPP Book, 2016 PPP Book 2017, PPP Book 2018, 2019 PPP Book, and 2020 PPP Book. This research also conducted a descriptive analysis through key stakeholder interviews including Airport Directorate DCGA Ministry of Transportation, Labuan Bajo Airport as a field operator, and the Directorate General of Financing and Risk Management Ministry of Finance. Methods for selecting key informant using snowball sampling.

Table 2. Key Informant

\begin{tabular}{lll}
\hline No. & \multicolumn{1}{c}{ Stakeholder } & \multicolumn{1}{c}{ Subject } \\
\hline 1 & DCGA Ministry of & - Representation of Planning Section, DGCA \\
& Transportation & - Representation of Airport Directorate, DGCA \\
& & - Labuan Bajo Airport Management Unit, DGCA \\
\hline $2 . \quad$ Ministry of Finance & - Representation of Directorate of Government Support Management \&. \\
& & Infrastructure Financing, Directorate General of Financing and Risk \\
& & Management \\
\cline { 3 - 4 } & & - Representation of Directorat of Loan \& Grants, Directorate General of \\
& & Financing and Risk Management \\
\hline
\end{tabular}

\section{RESULT AND DISCUSSION}

\subsection{Review of Proposed Planning based on PPP Book}

Based on the 2020-2024 National Medium-Term Development Plan (RPJMN), the direction of government financing policies is to encourage the use of funding sources from the public and the private sector 
through innovative financing schemes, including through the development of Public-Private Partnership (PPP) schemes as well as innovative forms of financing. To encourage Government and Business Entity Cooperation, Bappenas annually publishes a Public-Private Partnership (PPP) Book containing a list of planned activities to be financed through PPPs. The function of the PPP Book as a government planning document and to promote as well as monitor and evaluate the implementation of infrastructure provision implemented through the PPP scheme. The list of projects are expected to attract investors to participate in infrastructure financing in Indonesia. In the PPP Book, there are 2 categories of projects, namely projects in the process of preparation and ready to offer projects. All activities under the PPP scheme must be included in the PPP Book for further processing by the PPP stages, namely planning, preparation, and transaction. The description of the development process of public-private cooperation in the transportation sector in the last 10 years can be seen in the figure and Table 3. below. Based on figure 1, it can be described that road/highway development will be a favorable investment because bankable (profitable and high return). Comparable with the project in air transport, sea transport, and railway that relatively high cost, the limited capability of contractors, and long development period.

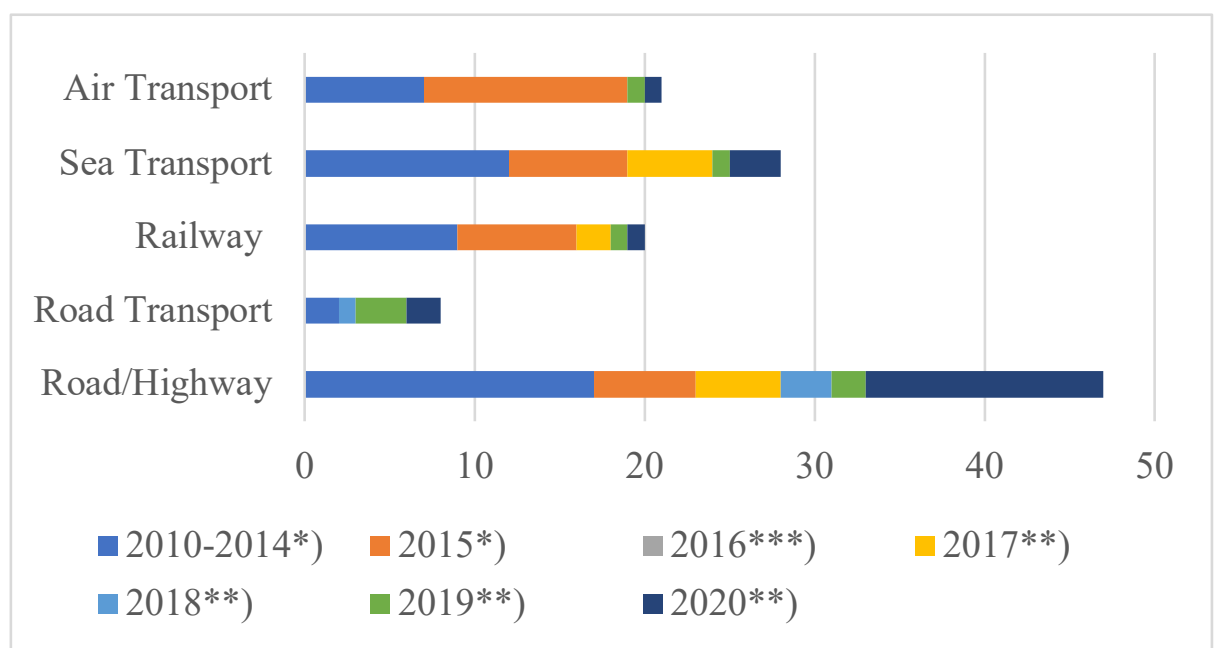

Figure 1. Progress Of Project Proposals In The PPP Book Source: PPP Book, 2010-2020

Notes:

*) PPP Book 2010-2014 and PPP Book 2015 still refer to Presidential Decree 67 of 2005 and the criteria for Cooperation in the PPP Book (ready for offering projects, priority/prospective projects, and potential projects)

**) The 2016-2020 PPP Book is based on Presidential Regulation Number 38 of 2015, so the PPP criteria consist of ready to offer projects and under-preparation projects.

***) PPP Book 2016 compiled in 2015 was not recorded in the 2017 PPP Book Evaluation

However, after Presidential Decree 38/2015, the PPP application has not been directly implemented by DGCA. It because they tends to prioritize funding with conventional approach, which is considered more flexible and easy to refocus. Furthermore, this condition shows a lack of commitment from policymakers (Bae and Joo 2016; Ismail 2013). It makes most of the projects promoted in the PPP Book drop and shift to others that are considered more efficient and easy financing sources. Therefore, need full effort to support changing the paradigm from conventional to creative financing. Considering that there have been low successful PPP projects in the field of transportation, a pilot project has been prepared for each sector. The implementation of this pilot project certainly requires conditioning government support to be successful and can be an example of other PPP implementations. Therefore, the preparation of the Labuan Bajo Airport PPP will be immediately included in the 2019-2020 PPP Book with the status of being tendered. In more detail in the air transportation 
sector, namely the Labuan Bajo Airport pilot project, the historical PPP project planning process is expected to describe the planning conditions, government funding priorities for the 2010-2020 period.

Table 3. Progress Of Air Transport Project Proposals in The PPP Book

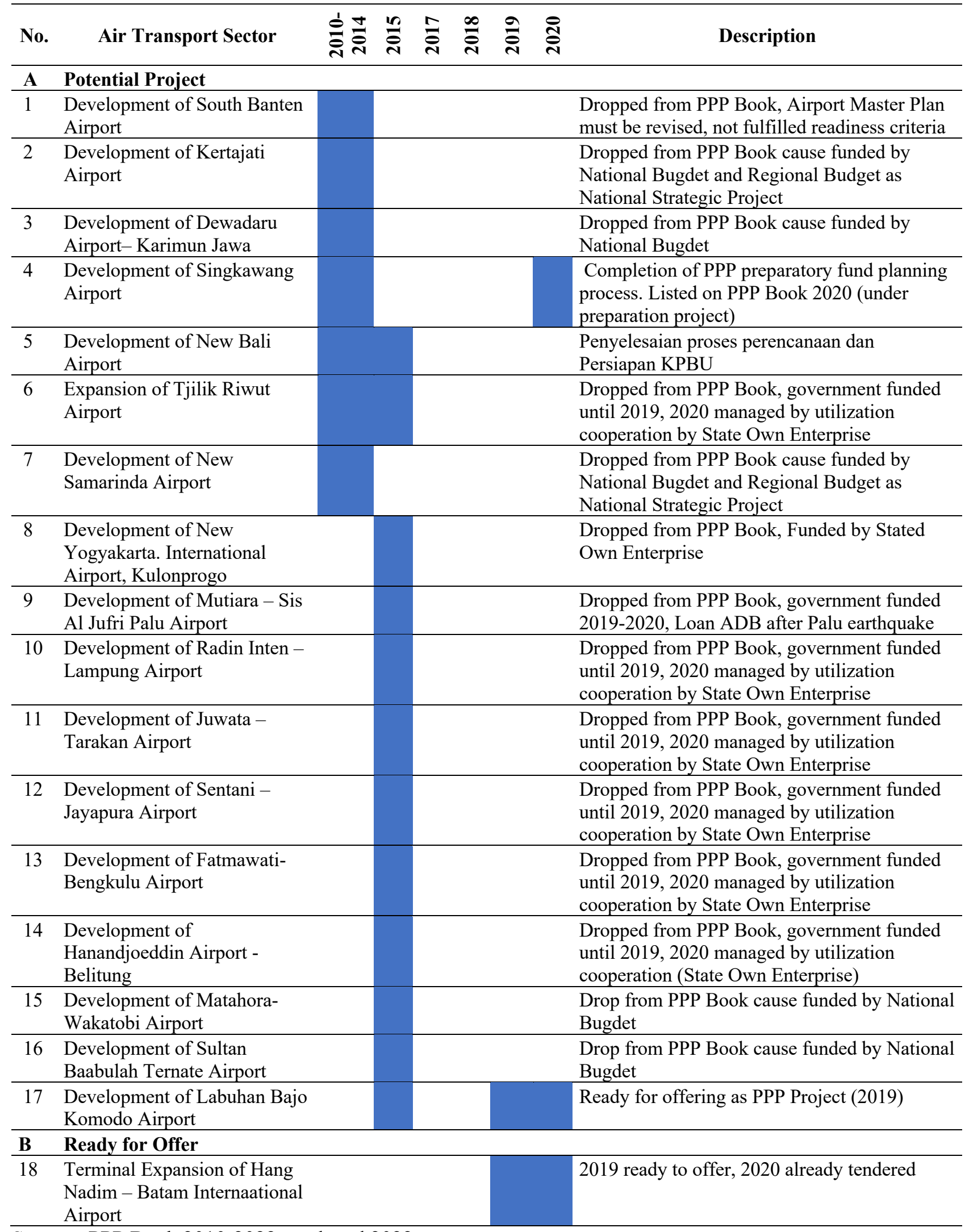

Source : PPP Book 2010-2022, analyzed 2022 
Based on the data above, it can be described that most of the Ministry of Transportation's projects (road, sea, railway, air transport) are only categorized as potential projects (2010-2015) and projects in preparation (2017-2019). The majority of projects handled by MOT are not ready to offer because of low compliance with readiness criteria. Potential projects based on Presidential Decree 67 of 2005, must be completed with preliminary studies covering compliance with the National Medium-Term Development Plan (RPJMN), conformity with the regional spatial plan (RTRW), linkages between the developed sector and regional development, potential cost recovery, and preliminary studies. The investment climate in 2010-2015 is lower than current because in 2020-2024 policymakers have arranged policies to simplify the investment process and incentives to attract investors (UU Cipta Kerja). Furthermore, most executing agencies lack understanding of PPP projects so they promote the big projects with high risk and long returns. Inadequate capacity of executing agency affects the capacity to select a project, prepare a proposal and choose the best scheme. It makes executing agencies promote imprecise projects that are suitable with the PPP concept. One thing has to be concerned with preparing PPP projects in contrast with conventional funding-based projects. It takes more than 2 years to prepare the readiness criteria for PPP Projects and this needs huge effort either central government or local government while conventional funding only needs 1 year. In addition, because of lack of capacity, they preferred to choose the easiest way of funding which is conventional funding (APBN).

\subsection{Labuan Bajo Airport Pilot Project Review}

The Labuan Bajo Airport PPP project includes an airport expansion and operation project to meet the minimum standard requirements. The financing scheme chosen for the development of Labuan Bajo Airport is implemented through Utilization Cooperation with a Design - Built - Finance - Operate - Maintenance Transfer scheme and a concession period of 25 years. In addition, the fund instrument uses the user charge method which takes earnings from the fraction of tariff admission. The purpose of this partnership is to improve performance and service to passengers, increase the number of passengers per year to 4,000,000 passengers and 3,500 tons of cargo by 2044, implement the 7th Nawacita and expand the national and international transportation sector (Directorate of Airports DGCA, 2020).

\subsubsection{Government Support Form}

As an effort to make the PPP pilot project a success and referring to the experience of previous PPP projects proposal, the state raised their support from both the Ministry of Transportation and other ministries and local governments. Given the position of the PPP project as a pilot project, it must be supported by various infestation climate policies that are able to facilitate the implementation of the PPP. Before studying further, the definition of government support and government guarantees based on regulations are as follows:

a) Government support is a financial contribution and or other forms provided by the Minister/Head of Institution/Head of Region and/or the Minister who administers government affairs in the field of finance and state assets in accordance with their respective authorities based on laws and regulations in order to improve the financial feasibility and effectiveness of PPPs. .

b) Government Guarantee is a financial compensation provided by the Minister who administers government affairs in the field of finance and state assets to the Implementing Business Entity through a cooperation risk-sharing scheme. Government guarantees are implemented through PT. Penjaminan \& Infrastruktur (PT. PII).

Government support form will be vary started from policymaking, top-down policies, budget support, preparation document support, and permit support to streamline the process of airport development and PPP implementation. It shows comprehensive support from Public Sector to promote PPP Implementation in airports sector. Detail government support form can be seen as follow : 


\begin{tabular}{|c|c|c|}
\hline No. & Stakeholder & Support \\
\hline 1. & $\begin{array}{l}\text { Central Government } \\
\text { Support (Bappenas, } \\
\text { Ministry of Finance, } \\
\text { Coordinative Ministry of } \\
\text { Maritime). }\end{array}$ & $\begin{array}{l}\text { The central government support to build good investation climate policy } \\
\text { that could attract investors are : } \\
\text { - The determination as Komodo as one of } 5 \text { Super Priority Tourism } \\
\text { Destinations by the President directed for Super Premium Destination to } \\
\text { capture middle to upper economic markets; } \\
\text { - Development of the Labuan Bajo Tourist Destination Complex } \\
\text { (Ministry of Tourism, Ministry of Public Works, MOT, PT. ASDP); } \\
\text { - Top-Down Policy including Budget determination for PPP Project } \\
\text { Preparation (OBC, FBC) in National Development Plan and } \\
\text { determination of Labuan Bajo Airport as a PPP Airport in a Joint Letter } \\
\text { of Budget Allocation Ceiling for the 2019-2021 Top-Down Policy } \\
\text { - Government Guarantee Support by PT PII }\end{array}$ \\
\hline 2 & $\begin{array}{l}\text { Ministry of Transportation } \\
\text { Support (as Executing } \\
\text { Agency) }\end{array}$ & $\begin{array}{l}\text { - FBC OBC Document Setup Preparation of the PPP Node as executing } \\
\text { agency to prepare Policy Formulation, Synchronization, Coordination } \\
\text { and supervision and evaluation of PPP development in accordance with } \\
\text { the mandate of Presidential Decree } 38 \text { of } 2015 \text { and Minister of National } \\
\text { Development } 4 / 2015 \text { Budget Support (2020-2021); } \\
\text { - Allocation for National Budget to improve project bankability including } \\
\text { Land Acquisition for extension, Transitional Hill Cutting, Runway } 17 \\
\text { Extension ( } 300 \mathrm{~m} \times 45 \mathrm{~m} \text { ), Terminal Interior Arrangement Work (MYC } \\
\text { 2020-2021), and Garbarata Installation }\end{array}$ \\
\hline 3 & $\begin{array}{l}\text { Regional and Local } \\
\text { Government Support } \\
\text { (Pemda NTT, Pemkab } \\
\text { West Manggarai) }\end{array}$ & $\begin{array}{l}\text { - The Governor of NTT and the Regent of West Manggarai agreed to } \\
\text { accelerate the land acquisition process Together with the Ministry of } \\
\text { Transportation to form a Land Acceleration Team; } \\
\text { - Relocation of roads affected by runway } 17 \text { extension in coordination with } \\
\text { Ministry of Public Works } \\
\text { - Grant of several parcels of land belonging to the Regional Government } \\
\text { that are included in the runway extension area; } \\
\text { - Support for the provision of supporting facilities for Super Priority } \\
\text { Tourism Destinations }\end{array}$ \\
\hline
\end{tabular}

Source: Ministry of Transportation, 2020

\subsubsection{Critical Success Factors and Barriers to PPP Projects}

In order to examine more deeply the factors that differentiate the PPP planning process in the Air Transportation sector, the PPP proposal process will be studied based on the Factors Affecting the Success of Infrastructure PPPs including financial and commercial, technical, political and legal, social factors (Ozdganm \& Birgonul, 2000; Ng et al., 2012, Bae \& Joo, 2015). Descriptive analyse will be done based on qualitative approach (in depth interview) with key stakeholder.

Table 5. Descriptive Analysis

\begin{tabular}{|c|c|c|c|}
\hline No & Factors & Factors Description & Descriptive Analysis \\
\hline 1. & $\begin{array}{l}\text { Financial } \\
\text { aspect } \\
\text { (Johnson, } \\
\text { McCormally, } \\
\text { \& Moore, } \\
\text { 2002; Forrer, } \\
\text { Kee, \& Zhang, } \\
\text { 2002; Ryan } \\
\text { and Menezess, } \\
\text { 2014), }\end{array}$ & $\begin{array}{l}\text { Financial feasibility } \\
\text { includes profitability, } \\
\text { economic stability, and the } \\
\text { ability to attract foreign } \\
\text { capital. PPPs with long } \\
\text { contract terms and large } \\
\text { scale tend to have a high } \\
\text { risk. Given the future } \\
\text { conditions of uncertainty } \\
\text { and uncontrollability that } \\
\text { the private sector does not } \\
\text { want to bear, the } \\
\text { government often bears } \\
\text { disproportionate risks } \\
\text { (Johnson, McCormally, \& }\end{array}$ & $\begin{array}{l}\text { - The potential demand for passengers from Labuan } \\
\text { Bajo Airport as market basic data of the DPSP } \\
\text { Premium. The highest potential demand can drive the } \\
\text { attraction of the PPP project offer to investors. The } \\
\text { PPP project was also implemented in undeveloped } \\
\text { airports that are already operational (brownfield) so } \\
\text { that the cooperation offered is in the form of Asset } \\
\text { Investment Cooperation (KSPI). The risk allocation } \\
\text { structure through the user charge refund scheme is } \\
\text { promoted by the Ministry of Finance. It is because } \\
\text { PPP offered with the AP scheme is considered to be } \\
\text { less risky and attract investors (high bankability). } \\
\text { Risk-sharing for location and political risk is handled } \\
\text { by public sector (PJPK), while risk of design, } \\
\text { construction, test operation, sponsorship risk, }\end{array}$ \\
\hline
\end{tabular}




\begin{tabular}{lll}
\hline No Factors & \multicolumn{1}{c}{ Factors Description } & \multicolumn{1}{c}{ Descriptive Analysis } \\
\hline Moore, 2002; Forrer, Kee, & $\begin{array}{l}\text { operation risk, and business risk handled by private } \\
\text { (BUP). The risk of force majeure and ownership of }\end{array}$ \\
& $\begin{array}{l}\text { assets are shared between PJPK and BUP. The } \\
\text { government also carries out Government Guarantees } \\
\text { through PT PII to overcome the problem of } \\
\text { uncertainty risk in the future. }\end{array}$ \\
& $\begin{array}{l}\text { The COVID-19 pandemic has delayed the financial } \\
\text { close process due to limited funding for the tender } \\
\text { winner (the effect of the decline in revenues and }\end{array}$ \\
& profits of PT. CAF's main business) \\
\hline
\end{tabular}

\begin{tabular}{|c|c|c|}
\hline 2. & $\begin{array}{l}\text { Economic \& } \\
\text { Technical } \\
\text { Aspect (van } \\
\text { Ham \& } \\
\text { Koppenjan, } \\
\text { 2001; (Tuan } \\
\text { Hai et al., } \\
\text { 2022; Liu, } \\
\text { Wang and } \\
\text { Wilkinson } \\
\text { 2016) }\end{array}$ & $\begin{array}{l}\text { The private sector can } \\
\text { contribute stable } \\
\text { management possibilities, } \\
\text { experience and capabilities } \\
\text { and innovative } \\
\text { technologies. Long-term } \\
\text { projects and large-scale } \\
\text { projects can eliminate } \\
\text { market competition. Hence, } \\
\text { a long-term monopoly only } \\
\text { for selected private } \\
\text { investors (van Ham \& } \\
\text { Koppenjan, 2001). }\end{array}$ \\
\hline 3. & $\begin{array}{l}\text { Positive legal } \\
\text { frameworks } \\
\text { (Ismail 2013, } \\
\text { Tuan Hai et } \\
\text { al., 2022; } \\
\text { Maramis 2018; } \\
\text { Estache and } \\
\text { Saussier 2014; } \\
\text { Hwang, Zhao } \\
\text { and Gay 2013) }\end{array}$ & $\begin{array}{l}\text { The stable climate } \\
\text { investment present through } \\
\text { stable and experienced } \\
\text { government environment, a } \\
\text { transparent and competitive } \\
\text { tender system. This } \\
\text { condition has supported by } \\
\text { regulations and } \\
\text { institutional frameworks } \\
\text { that encourage PPP } \\
\text { implementation }\end{array}$ \\
\hline 4. & $\begin{array}{l}\text { Social Issue } \\
\text { (Ng, Wong } \\
\text { and Wong } \\
2012 \text { ) }\end{array}$ & $\begin{array}{l}\text { Social acceptance for } \\
\text { community lives around } \\
\text { project construction and if } \\
\text { the airport has operated, } \\
\text { then community concerns } \\
\text { about service quality } \\
\text { enhancement }\end{array}$ \\
\hline
\end{tabular}

The Labuan Bajo PPP scheme with a concession period of 25 years, PPP bidder in the airport sector are scarce, besides that the private sector is unable to fulfill the passenger charge calculation of Rp. 60.000,-/passenger determined by the Ministry of Transportation. Only 1 private party that meets the qualifications (CAS and Changi consortium) with a modified user charge. The purpose of the PPP is also to open up opportunities for airport management actors so that they can increase the competitiveness of airport services and no monopoly in airport services. In addition, Indonesia government also support with UUCK to make investation process easier than before by integrating several laws.

The existence of guarantee of legal certainty is implemented through PPP regulations that make it easier for the private sector (PP 38/2015, government guarantees) and directs the Minister to support PPP implementation through various top-down policies. In order to enhance the feasibility of the project, the government supports financing activities sourced from the APBN to gain the financial feasibility of the airport's state capital participation.

The community will not be particularly affected by shift financing. Labuan Bajo Airport remain managed by the DJU (UPBU Komodo - Labuan Bajo) so there has been no change in service prices. Based on the results of the auction, it is plausible to increase the service fee as improvement services. The passenger will concerned with service quality enhancement because this airport improves the level of international airports. The community around the airport accepted the expansion of Labuan Bajo Airport since this airport will be a gateway for tourism and promote their region. When tourism demands improve, it will alleviate the economic region and prosperous community.

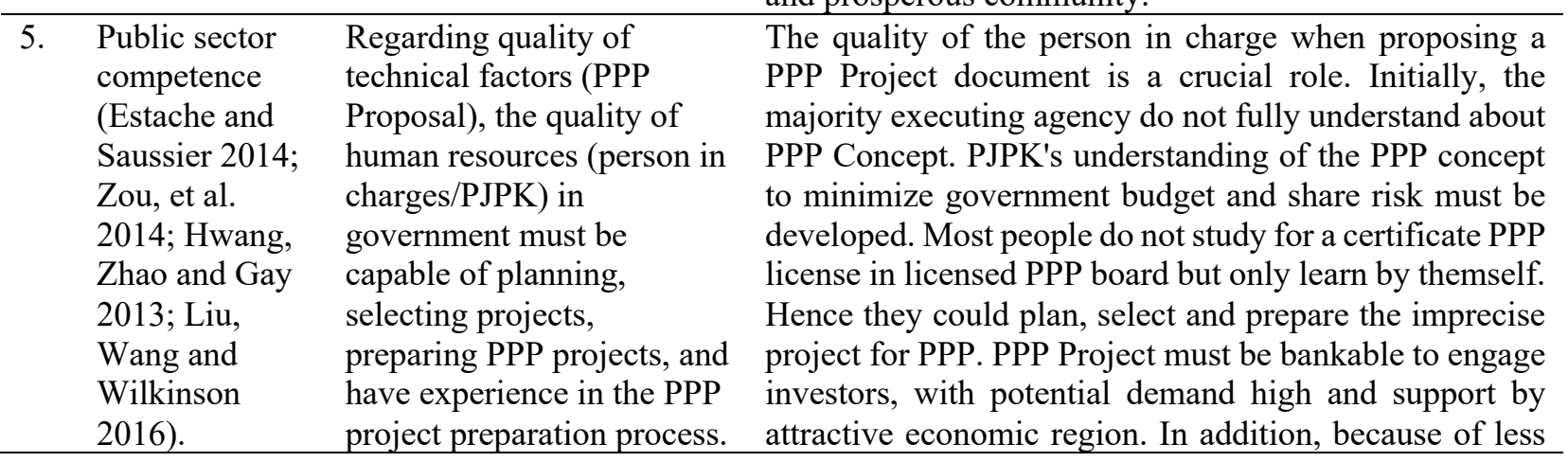




\begin{tabular}{|c|c|c|c|}
\hline No & Factors & Factors Description & Descriptive Analysis \\
\hline & & & $\begin{array}{l}\text { understanding of the person in charge and limited target } \\
\text { time so most PPPs that have been proposed in PPP Book } \\
\text { are dropped from the list. It shows that executing agency } \\
\text { less commitment to promote PPP Policy. }\end{array}$ \\
\hline
\end{tabular}

Source: Data Analyze, 2021

\section{CONCLUSIONS}

Based on the description analysis, here is several important conclusions were obtained as follows: 1) PPP can be a financing solution through the arrangement of the private sector to join in the sharing of authority, responsibility, resources, risks, and benefits from the provision of public services and infrastructure (Hodge \& Greve, 2007; Grimsey \& Lewis, 2004). However, the scale of the project, the length of the concession period also limit the number of qualified investors who will participate in the PPP auction. Investors will also be more interested in bankable projects, there is legal certainty, guarantees, and government support so that investors can minimize uncertainty in the future. 2) Based on the historical study of the PPP Book 2010-2020, it is known that the PPP project proposal process in the 2010-2018 period was less supported by the government policy and experienced human resources who prepare PPP projects so the readiness criteria of PPP supporting documents (preliminary study, OBC, market sounding, FBC) could not be fulfilled in short term. This is also supported by urgent funding needs so that PPP financing is diverted to other financing schemes (APBN, BUMN) which are considered easier to propose. 3) By referring to experience and results of descriptive analysis, it can be seen that the factors that influence the success of PPP projects in the transportation sector in Indonesia are Government Competence (Human Resources/executing agency that can select financial feasibility of the project, technical capability and experience of PPP, and legal and political support by the government through the provision of regulations that facilitate the PPP process and government support. Most of the factors that play a role in this area at the PPP preparation/planning stage include the preparation of a comprehensive and reliable project (Preliminary Study, OBC, and FBC), land, government support, licensing to minimize uncertainty for the private sector/investor and attract investors and 4) Obstruct factors (threat) to the implementation of the Labuan Bajo PPP project are changes in the strategic environment such as a pandemic condition that makes the financial capacity of PT. CAF could delay the financial close process. However, it turns out that financial close delays have also occurred at others sectors such as PLTU Batang and KA Makassar - Pare-Pare due to land acquisition problems.

The constraint of this research because only takes 1 (one) case pilot project and does not correlate to other PPP Projects around the world. It should be more efficient and advantageous if the research discusses PPP in the transport sector as a whole. In addition, future research can categorize PPP funding schemes as examples for availability payment and user charges. Knowing the differences can benefit to find key success factors and the obstructing factor in PPP implementation. Moreover, this research only uses qualitative approaches with key stakeholder dialogue. Future research must be developed combining a qualitative approach with a quantitative approach to gain further and statistic-based information.

\section{ACKNOWLEDGMENTS}

The author would like to thank Prof. Pradono as supervisor of the development financing class in SAPPK ITB that gives feedback to complete this paper.

\section{REFERENCES}

Aladag, H., \& Isik, Z. (2018). The Effect of Stakeholder-Associated Risks in Mega-Engineering Projects: A Case Study of a PPP Airport Project. IEEE Transactions on Engineering Management, 113. doi:10.1109/tem.2018.2866269

Bae, Yooil, and Yu-Min Joo. (2016). "Pathways to meet critical success factors for local PPPs: The cases of urban transport infrastructure in Korean cities. ." Cities 53(), 35-42. doi:10.1016/j.cities.2016.01.007 
Carnis, L., \& Yuliawati, E. (2013). Nusantara: Between sky and earth could the PPP be the solution for Indonesian airport infrastructures? https://doi.org/10.1016/j.cstp.2013.08.003

Engel, E., Fischer, R., \& Galetovic, A. (2018). The joy of flying: Efficient airport PPP contracts R. Transportation Research Part B, 114, 131-146. https://doi.org/10.1016/j.trb.2018.05.001

Estache, Antonio, and Stephane Saussier. (2014). "Public-Private Partnerships and Efficiency: A Short Assessment." EPPP DP 1-12.

Fleta-Asín, J., \& Muñoz, F. (2020). How does risk transference to private partner impact on public-private partnerships' success? Empirical evidence from developing economies. Socio-Economic Planning Sciences, 72. https://doi.org/10.1016/j.seps.2020.100869

Forrer, J., Kee, J.E., \& Zhang, Z. (2002). Private finance initiative: A better public-private partnership? Public Manager, 31(2), 43-47.

Gardaindonews. (2018), Sri Mulyani: Perubahan Paradigma Pembiayaan Infrastruktur Butuhkan Stabilitas Ekonomi Makro, available at: https://www.gardaindonews.com/sri-mulyani-pembiayaan-infrastrukturbutuhkan-stabilitas-ekonomi-makro/ (accessed Desember 2021)

Grimsey, D., \& Lewis, M. (2004). Public-private partnerships: The worldwide revolution in infrastructure provision and project finance. Cheltenham: Edward Elgar.

Hodge, Graeme, \& Greve, Carsten. (2007). Public-private partnerships: An international performance review. Public Administration Review, 67(3), 545-559

Hwang, B-G, X Zhao, and JMS Gay. 2013. "Public-private partnership projects in Singapore: factors, critical risks and preferred risk allocation from the perspective of contractors." Int J Project Manage 31(3):424433.

Idris, M. (2020), Bandara Komodo Bukan Dijual, Tapi Dikelola Swasta Selama 25 Tahun, available at:https://money.kompas.com/read/2020/02/08/105634526/bandara-komodo-bukan-dijual-tapidikelola-swasta-selama-25-tahun?page=all. (accessed Desember 2021)

Indonesia Ministry of National Development Planning (Bappenas). (2016). Buku Saku KPBU. Bappenas : Jakarta

Indonesia Ministry of National Development Planning (Bappenas). (2010). Public-Private Partnership (PPP) Book 2010-2014. Bappenas: Jakarta

Indonesia Ministry of National Development Planning. (2014). Public-Private Partnership (PPP) Book 2015. Bappenas: Jakarta

Indonesia Ministry of National Development Planning. (2016). Public-Private Partnership (PPP) Book 2017. Bappenas: Jakarta

Indonesia Ministry of National Development Planning. (2017). Public-Private Partnership (PPP) 2018. Bappenas: Jakarta

Indonesia Ministry of National Development Planning. (2018). Public-Private Partnership (PPP) Book 2019. Bappenas: Jakarta

Indonesia Ministry of National Development Planning. (2019). Public-Private Partnership (PPP) Book 2020. Bappenas: Jakarta

Ismail, S. 2013. "Critical success factors of public-private partnership (PPP) implementation in Malaysia." Asia-Pacific Journal Business Administration 5:6.

Johnson, Robin A., John McCormally, and Adrian T. Moore. (2002). "Long-term Contracting for Water and Wastewater Services.” How-to Guide No. 19. Los Angeles, CA: Reason Foundation. Available online at http://www.rppi.org/htg19.pdf

Liu, T., Y. Wang, and S. Wilkinson. (2016). "Identifying critical factors affecting the effectiveness and efficiency of tendering processes in public-private partnerships (PPPs): A comparative analysis of Australia and China." International Journal of Project Management, 34(4) 701-716. doi:10.1016/j.jproman.2016.01.004.

Maramis, Joubert B. (2018). "Faktor Faktor Sukses Penerapan Kpbu Sebagai Sumber Pembiayaan Infrastruktur : Suatu Kajian." Jurnal Manajemen Bisnis dan Inovasi Universitas Sam Ratulangi 49-63.

MediaIndonesia. (2020), Bandara Labuan Bajo Segera Naik Kelas, available at:https://mediaindonesia.com/ekonomi/288580/bandara-labuan-bajo-segera-naik-kelas ～(accessed Desember 2021)

Minister of Transportation Regulation Number PM 5/2018 concerning Procedures for Implementing PPPs in the Provision of Transportation Infrastructure within the Ministry of Transportation

Nawawi, H., (2003). Metode Penelitian Bidang Sosial. Yogyakarta : Gadjah Mada University Press.

Ng, S. T., Wong, Y. M., \& Wong, J. M. (2012). Factors influencing the success of PPP at feasibility stage-A tripartite comparison study in Hong Kong. Habitat International, 36(4), 423-432 
Ozdganm, I.D., \& Birgonul, M.T. (2000). A decision support framework for project sponsors in the planning stage of the build-operate-transfer (BOT) projects. Construction Management and Economics, 18(3), 343-353.

Presidential Regulation of the Republic of Indonesia Number 18/2020 concerning RPJMN 2020-2024

Presidential Regulation of the Republic of Indonesia Number 38/2015. About Government Cooperation with Business Entitled

Ryan, M., and F. Menezes. 2014. "Public-private partnerships for transport infrastructure: Some efficiency risks." New Zealand Economic Papers 49(3), 276-295. doi:10.1080/00779954.2014.955625.

Sugimura, Yoshihisa; Kato, Azuma. 2022. Airport concession in Japan: Current status, problems, and future directions. Research in Transportation Business \& Management. https://doi.org/10.1016/j.rtbm.2021.100738

Tuan Hai, D., Quoc Toan, N., \& van Tam, N. (2022). Critical success factors for implementing PPP infrastructure projects in developing countries: the case of Vietnam. Innovative Infrastructure Solutions, 7, 89. https://doi.org/10.1007/s41062-021-00688-6

Van Ham, H., \& Koppenjan, J. (2001). Building public-private partnerships: assessing and managing risks in port development. Public Management Review, 4(1), 593-616.

Wibowo, Farid Arif. 2017. "Meningkatkan Kualitas APBN dengan Skema KPBU." Info Risiko Fiskal, April: 4-9.

Zou, Weiwu, Mohan Kumaraswamy, Jacky Chung, and James Wong. 2014. "Identifying the critical success factors for relationship management in PPP projects." International Journal of Project Management 265274. 